\title{
Peningkatan Loyalitas Nasabah Bank BPR-BKK Melalui 3 P'S Marketing Mix di Kabupaten Demak
}

\author{
Nurchayati \\ Fakultas Ekonomika Dan Bisnis, Universitas 17 Agustus 1945 Semarang \\ nurchayatiuntag@gmail.com
}

Ribut Musprihadi

Fakultas Ekonomika Dan Bisnis, Universitas 17 Agustus 1945 Semarang

ributmusprihadi@gmail.com

\section{Suparmi}

Fakultas Ekonomika Dan Bisnis, Universitas 17 Agustus 1945 Semarang suparmi.untag@yahoo.com
Abstrak
Tujuan dari penelitian ini adalah untuk menguji" $3 \mathrm{P}$ (people, physical dan evidence, process atau people, physical, evidence dan proses) dalam loyalitas nasabah di PT BPR BKK Demak (Regional) melalui kepuasan nasabah sebagai variabel mediasi. Besar sampel adalah 189 nasabah bank BPR-BKK. Teknik pengambilan sampel dilakukan dengan dua cara yaitu proportional random sampling dan Purpusive random sampling. Metode "analisis yang digunakan adalah analisis jalur".
Hasil penelitian yang didapatkan 3 P'S marketing mix memiliki dampak positif dan signifikan terhadap" loyalitas pelanggan bila didukung dengan kepuasan pelanggan. Kepuasan nasabah merupakan salah satu kunci sukses bisnis perbankan, agar konsumen tidak kecewa dan pindah ke bank lain. Kepuasan pelanggan mempengaruhi pengambilan keputusan untuk membeli kembali atau melanjutkan layanan yang sama. Layanan berkualitas melalui 3P'S marketing mix untuk meningkatkan kepuasan pelanggan dan secara tidak langsung menciptakan loyalitas dan loyalitas pelanggan diperoleh melalui peningkatan hubungan pelanggan jangka panjang.
Kata kunci people, physical evidence, proses, kepuasan nasabah dan loyalitas nasabah"

\section{PENDAHULUAN}

Persaingan yang ketat di industri perbankan menuntut setiap Bank untuk memberikan pelayanan yang terbaik kepada nasabahnya, baik secara kuantitas dengan menambah produk yang dianggap akan memenuhi keinginan pelanggannya, maupun kualitas dengan pelayanan yang berorientasi pada kepuasan nasabah. Persaingan perbankan yang tinggi atau ketat ini, memiliki hubungan negatif dengan stabilitas ekonomi karena mengurangi profitabilitas bank (Adhamovna, 2016; Koskela, E. dan R. Stenbacka, 2000). Alasannya, meningkatnya persaingan antar bank akan 
menurunkan suku bunga kredit, menurunkan bahaya gagal bayar debitur, dan dengan demikian menjamin stabilitas ekonomi dan sistem perbankan (Wijoyo, 2021).

Kepuasan pelanggan merupakan salah satu rahasia kesuksesan bagi perusahaan. Banyak bisnis gagal karena kekecewaan pelanggan sehingga membuat nasabah beralih ke bank lain yang dianggap lebih baik. Memberikan pelayanan berkualitas merupakan tujuan agar pelanggan mendapatkan kepuasan, sehingga dapat membangun loyalitas nasabah melalui peningkatan nasabahnya. Pendapat tersebut diperkuat dengan hasil penelitian (Bahari \& Siaga, 2018), yang menyatakan kepuasan berpengaruh pada loyalitas.

Loyalitas nasabah merupakan keputusan nasabah untuk secara suka rela terus berlangganan dengan perusahaan tertentu dalam jangka waktu yang lama (Lovelock \& Wright, 2018) . Loyalitas akan berlanjut hanya sepanjang nasabah merasakan bahwa nasabah menerima nilai yang lebih baik dibandingkan penyedia jasa lain. Dalam membangun loyalitas nasabah dibutuhkan strategi bauran pemasaran atau marketing mix. Tidak hanya 4P'S, tapi perlu bauran pemasaran yang diperluas dengan penambahan unsur non-traditional marketing mix, yaitu $3 \mathrm{P}$ yaitu people, physical evidence, dan process, yang merupakan unsur fundamental bagi pihak perbankan, karena merupakan bagian dalam menunjang terciptanya kepuasan nasabah. Bauran pemasaran (7P) jasa terdiri dari: product, price, promotion, place, people, physical evidence serta process. Namun Nugroho \& Japarianto (2013) menemukan dalam penelitian pada perusahaan jasa bahwa, karyawan dan staff (people) yang baik dan sopan dapat membuat nasabah merasa nyaman dan kemudian memutuskan untuk datang kembali. Perlengkapan, desain dan tata ruang (physical evidence) yang nyaman, bersih dan rapi telah membuat nasabah tertarik untuk berkunjung. Demikian pula dengan pelayanan yang baik disertai dengan selalu bertutur kata sopan dan tanggap dalam melayani konsumen (process). Masitha \& Zaini, (2018) menyatakan dari penelitiannya ternyata people, physical evidence, dan process termasuk marketing mix sebagai unsur yang terpisah, karena unsur ini dalam pengawasan perusahaan yang mempengaruhi keputusan awal pembeli pada sebuah layanan, juga mempengaruhi tingkat kepuasan pelanggan dan keputusan pembelian ulang. Hasil penelitian tersebut mengindikasikan bahwa pada perusahaan jasa, unsur people, physical evidence serta process merupakan unsur bauran pemasaran yang dominan pada perusahaan jasa, demikian juga pada perusahaan perbankan.

$\mathrm{P}$ pertama adalah people. people atau karyawan merupakan faktor yang sangat penting kedudukannya, dalam pelayanan perbankan. Pelayanan perbankan yang bermutu harus ditunjang adanya karyawan yang profesional. Pernyataan tersebut mendukung pendapat (Tjiptono F. , 2015), bahwa people atau kemampuan karyawan merupakan unsur vital dalam bauran pemasaran karena didalam industri jasa setiap karyawan merupakan" parttime markerter". Pernyataan tersebut sejalan dengan (Lovelock \& Wright, 2018), bahwa people yang berinteraksi langsung dengan konsumen didalam memberikan layanan, merupakan bagian penting untuk membangun kepuasan, serta membangun loyalitas nasabah. Pendapat ini didukung hasil penelitian (Bahari \& Siaga, 2018) serta (Hadinnisa, 2018) yang menunjukkan bahwa people berpengaruh terhadap loyalitas konsumen.

P yang Kedua adalah Process, Process dalam pelayanan perbankan adalah hal yang penting, pendapat tini didukung (Hurriyati, 2005), yang menyatakan proses dalam jasa merupakan faktor utama dalam marketing mix jasa. (Lovelock \& Wright, 2018), menjelaskan, bila proses yang dilalui konsumen dalam bertransaksi cukup sederhana dan tidak merugikan pikiran, waktu, dan tenaga, maka konsumen akan merasa puas, bahkan menjadi loyal. Pernyataan tersebut didukung (Denove \& 
Power, 2007), bahwa kepuasaan konsumen merupakan komponen yang sangat menentukan bagi terciptanya loyalitas konsumen.

P yang ketiga adalah Physical evidence. Physical evidence. merupakan petunjuk visual atau berwujud lainnya yang memberi bukti atas kualitas jasa (Lovelock \& Wright, 2018). Physical Evidence yang memadai, baik dari segi kecanggihan, kebersihan dan lain sebagainya juga merupakan hal yang sangat penting dalam kualitas pelayanan perbankan. (Lupiyoadi, 2001), mengungkapkan bahwa kualitas pelayanan yang bermutu yang ditunjukkan kepemilikan perusahaan dari unsur tangibles atau fasilitas fisik merupakan salah satu aspek yang menentukan kepuasan pelanggan. (Hadinnisa, 2018), membuktikan bahwa physical evidence, berpengaruh signifikan terhadap kepuasan pelanggan. Pelanggan yang puas akan kembali membeli produk yang sama dan cenderung memberikan persepsi positif terhadap produk perusahaan, sehingga diharapkan akan membangun loyal nasabah.

Penelitian ini dilakukan karena adanya hasil yang inkonsisten ( research gap ) dari beberapa hasil penelitian sebelumnya. Noviana, (2013) menunjukkan bahwa ada pengaruh yang signifikan membuktikan bahwa terdapat pengaruh antara 3P'S Marketing mix secara signifikan terhadap kepuasan. Kepuasan pelanggan berpengaruh positif signifikan terhadap loyalitas pelanggan (Al Afifah, 2016). Strategi pemasaran 3P berpengaruh terhadap loyalitas konsumen (Bahari \& Siaga, 2018). Hasil penelitian (Hadinnisa, 2018), (Putra \& Sulistyawati , 2013), juga membuktikan, adanya pengaruh 3P'S Marketing mix terhadap kepuasan nasabah, dan kepuasan nasabah berpengaruh terhadap loyalitas nasabah. Sedangkan pada penelitian (Sanjaya \& Yuliastanty, 2016) dengan intervening kepuasan pelanggan, menunjukkan sebaliknya bahwa 3P'S tidak berpengaruh terhadap loyalitas konsumen. (Farida, 2016), juga memberikan hasil yang berbeda, dimana 3P'S Marketing mix tidak berpengaruh signifikan terhadap kepuasan pelanggan. Begitu pula penelitian yang dilakukan oleh Penelitian (Soelasih, 2016), membuktikan bahwa physical evidence tidak berpengaruh terhadap kepuasan. Sementara penelitian lain yang dilakukan oleh (Maulana, 2010), membuktikan bahwa kepuasan tidak berpengaruh terhadap loyalitas. Hal ini menunjukkan pengaruh 3P'S Marketing mix terhadap loyalitas konsumen diperoleh hasil yang berbeda, di satu sisi berpengaruh, tetapi di sisi lain tidak berpengaruh.

Sudiryanto (2011), dalam penelitiannya di PT. BPR BKK Demak (Perseroda) menunjukkan bahwa ketidakpuasan nasabah yang muncul berupa keluhan nasabah, seperti birokrasi, intensitas komunikasi yang kurang memadai sehingga transaksi nasabah fluktuatif atau cenderung tidak berjalan. Kajian ini mencoba menciptakan pola pikir berdasarkan asumsi bahwa sasaran utama upaya pemasaran bukanlah benar-benar mencapai kepuasan pelanggan, tetapi bagaimana keberhasilan dengan dukungan melalui strategi 3P Marketing mix dapat menghasilkan loyalitas pelanggan dengan terus membangun hubungan baik berkelanjutan (Tjiptono F. , 2015). Permasalahan dalam penelitian ini adalah ; “Apakah 3P'S marketing mix (people, process, dan physical evidence) berpengaruh terhadap loyaliatas nasabah dengan intervening kepuasan nasabah Bank BPR- BKK Kabupaten Demak ?" 


\section{JESYN}

JURNAL EKONOMI \& EKONOMI SYARIAH

Jurnal Ekonomi \& Ekonomi Syariah Vol 5 No 1, Januari 2022

E-ISSN : 2599-3410 | P-ISSN : 2614-3259

DOI : https://doi.org/10.36778/jesya.v5i1.530

\section{LANDASAN TEORI"}

\section{A.1. Loyalitas Pelanggan}

Konsumen menggunakan waktu berdasarkan kebiasaan konsumen dan keinginan untuk tetap loyal (Aaker, 2013). Loyalitas juga diartikan sebagai pembelian berulang oleh konsumen (Alma, 2013). Pandangan ini berbeda dengan pandangan (Tjiptono F. , 2015) loyalitas merupakan layanan yang secara konsisten diterima oleh konsumen. Menurut (Lovelock \& Wright, 2018), loyalitas konsumen adalah pilihan konsumen untuk bertindak secara sukarela khususnya dalam jangka waktu panjang berlangganan pada suatu perusahaan. Jadi loyalitas hanya akan bertahan selama konsumen merasa mendapatkan nilai yang lebih baik (termasuk nilai uang yang lebih baik) daripada apa yang mereka dapatkan dari penyedia layanan lain. Ketika perusahaan melakukan hal-hal yang mengecewakan konsumen, atau ketika pesaing mulai memberikan yang lebih baik, ada risiko konsumen akan berubah atau berpindah (Lovelock \& Wright, 2018).

Beberapa perusahaan membuat mekanisme untuk menjaga merek dapat tetap diingat oleh konsumen (Kotler \& Keller, 2014). Konsumen yang loyal akan membeli produk yang ditawarkan oleh produsen. Pelanggan menyarankan temannya untuk membeli produk yang sama di tempat yang sama dan tidak terburu-buru ke produk pesaing (Alma, 2013). Itulah mengapa sangat penting untuk mempertahankan pelanggan. Retensi konsumen merupakan upaya perusahaan untuk mendatangkan pelanggan, termasuk pengeluaran uang secara teratur, pengambilan keputusan pelanggan tidak akan berubah dalam jangka panjang. Penciptaan hubungan yang kuat dan dekat dengan konsumen adalah impian sepeople pemasar, karena itu adalah kunci sukses pemasaran jangka panjang (Kotler \& Keller, 2014).

Menurut (Kotler \& Keller, 2014), ada empat jenis utama pemasaran yang digunakan perusahaan untuk meningkatkan aktivitas loyalitas dan kesetiaan (feel to have), yaitu: (1). interaksi dengan konsumen: (2). pengembangan program loyalitas; (3). personalisasi pemasaran: dan (4). tautan institusional. Pelanggan adalah aset bisnis, komitmen, pelanggan setia, bank harus dapat menawarkan produk atau layanan yang dapat memenuhi harapan pelanggan dan memuaskan pelanggan. Loyalitas pelanggan dipengaruhi oleh beberapa faktor, yaitu: kepercayaan, kepuasan, komitmen. Sikap, citra perusahaan dan kualitas layanan dan produk (Kotler, 2000). Sedangkan indikator loyalitas pelanggan yang digunakan disini (Griffin, 2005) dan (Studi Shafitranata, 2019), yaitu: (1). pembelian ulang, (2). jangan beralih ke pesaing; (3). informasi positif: (4). rekomendasi untuk people lain: dan (5). penolakan produk lain.

\section{A.2. Kepuasan Konsumen}

Kepuasan (Haryanto, 2013) menunjukkan bahwa kepuasan konsumen adalah tingkat perasaan setelah membandingkan kinerja (hasil) yang diharapkan dengan harapan. Pandangan ini sejalan dengan (Tjiptono F. , 2015) bahwa konsumen merupakan perbandingan antara ekspektasi atau ekspektasi pra pembelian dengan persepsi kinerja pasca pembelian. Selain itu, (Tjiptono F. , 2008) menemukan bahwa konsumerisme adalah tanggapan konsumen terhadap penilaian kesenjangan antara harapan sebelumnya dan kinerja aktual produk setelah digunakan. (Kotler \& Keller, 2014) menemukan kepuasan pelanggan sebagai rasa senang atau kecewa masyarakat akibat membandingkan kinerja produk (atau produk) yang dirasakan dengan yang diharapkan. Dengan demikian, kepuasan konsumen hanya terlihat ketika konsumen merasa puas dengan pelayanan yang diterima. Jika mereka tidak puas, konsumen akan mengubah produk atau merek mereka dan mengajukan keluhan kepada produsen komoditas, pengecer, dan konsumen lainnya (Peter \& Jerry , 


\section{JESYN}

JURNAL EKONOMI \& EKONOMI SYARIAH

Jurnal Ekonomi \& Ekonomi Syariah Vol 5 No 1, Januari 2022

E-ISSN : 2599-3410 | P-ISSN : 2614-3259

DOI : https://doi.org/10.36778/jesya.v5i1.530

2014). Selain itu, kepuasan dapat membentuk persepsi dan posisi produk perusahaan di mata pelanggan.

Teori dan pendekatan yang digunakan dalam survei kepuasan adalah kegagalan untuk menegaskan harapan dengan pendekatan utilitas. Pendekatan ini menganggap kepuasan konsumen sebagai tingkat kepuasan atas pemenuhan yang terkait dengan kemampuan perusahaan sampai sejauh mana untuk menyediakan suatu produk atau jasa kebutuhan pelanggan. Kegunaan produk dapat melebihi harapan pelanggan (Peter \& Jerry , 2014). Ada tiga jenis konfirmasi palsu kegunaan produk, yaitu konfirmasi positif palsu, konfirmasi negatif palsu, dan konfirmasi netral palsu. Non-konfirmasi positif adalah ketika kegunaan produk lebih baik dari yang diharapkan. Situasi ini diyakini akan menghasilkan pengalaman yang memuaskan atau tidak memuaskan. Dalam hal ini, harapan konsumen tidak begitu positif dan teorinya adalah konsumen dapat dipuaskan. Non-konfirmasi negatif terjadi ketika penggunaan produk lebih rendah dari yang diharapkan. Situasi ini dianggap tidak memuaskan. Pernyataan non-netral terjadi ketika pemahaman tentang utilitas hanya dapat diharapkan. Apakah konsumen puas dalam hal ini tergantung pada variabel lain, seperti tingkat harapan dan utilitas (Peter \& Jerry , 2014). Jika pengalaman lebih besar atau setidaknya tidak sama dengan yang diharapkan sebelum membeli, konsumen akan puas. Jika tidak maka akan merasa tidak puas (Tjiptono F. , 2015). Harapan akan tumbuh dari pengalaman membeli sebelumnya, saran dari teman dan mitra, serta informasi dan janji dari pedagang dan pesaing. Ekspektasi yang berlebihan akan mengecewakan pembeli. Sebaliknya, harapan yang sangat rendah tidak akan cukup menarik pembeli, bahkan jika perusahaan dapat memuaskan pembeli. Beberapa perusahaan menciptakan harapan dan memberikan layanan yang sesuai dengan harapan (Kotler \& Keller, 2014).

Menciptakan kepuasan pelanggan dapat memberikan sejumlah manfaat, antara lain hubungan yang harmonis antara perusahaan dan konsumen, landasan yang baik untuk bisnis yang berulang dan loyalitas pelanggan, serta merumuskan rekomendasi yang positif dan menguntungkan bagi perusahaan. (Tjiptono F. , 2015). Konsumen seringkali menciptakan persepsi positif tentang suatu produk atau merek yang mereka anggap positif. Jika kinerja tidak sesuai yang diharapkan, konsumen akan tidak puas. Jika kinerja sesuai dengan yang diharapkan, konsumen akan puas. Jika kinerja melebihi harapan, konsumen akan sangat puas atau senang (Kotler \& Keller, 2014). Kepuasan konsumen yang lebih tinggi juga dikaitkan dengan hasil yang lebih tinggi dan risiko yang lebih rendah di pasar Kotler \& Keller, 2014). Kepuasan konsumen yang diperoleh melalui pengalaman langsung memperburuk pengaruh kepercayaan itu. Kepuasan dan ketidakpuasan konsumen terhadap produk mempengaruhi perilaku berikut. Jika konsumen puas, mereka dapat membeli produk yang sama lagi. Konsumen juga cenderung akan puas memilih produk/referensi layanan yang direferensikan kepada people lain. Pendorong utama adalah tindakan konsumen. Pelanggan merasa puas dengan produk/jasa yang ditawarkan perusahaan, seperti tidak ada keluhan, rasa puas dan memenuhi harapan, dapat mempengaruhi loyalitas konsumen.

Beberapa hasil penelitian sebelumnya menyimpulkan bahwa kepuasan konsumen berpengaruh terhadap loyalitas konsumen. (Simamora, 2007, Sanjaya \& Yuliastanty, 2016, dan Shafitranata, 2019) Berdasarkan uraian tersebut, kita dapat mengasumsikanberikut

$\mathrm{H}_{4}$ : Loyalitas pelanggan kepuasan pelanggan mempengaruhi

\section{A.3. $\quad 3$ P'S Marketing Mix}

Marketing mix strategy adalah sarana yang digunakan oleh pemasar dapat untuk membentuk karakteristik layanan yang ditawarkan kepada pelanggan (Tjiptono F. , 2011). Alat ini dapat digunakan untuk merancang program taktis jangka pendek, program taktis jangka menengah 


\section{JESYN}

JURNAL EKONOMI \& EKONOMI SYARIAH

Jurnal Ekonomi \& Ekonomi Syariah Vol 5 No 1, Januari 2022

E-ISSN : 2599-3410 | P-ISSN : 2614-3259

DOI : https://doi.org/10.36778/jesya.v5i1.530

dan panjang (Tjiptono F. , 2011) jasa termasuk produk, harga, iklan, lokasi, people, process, physical evidence, dan layanan. (Hurriyati, 2005) menguraikan bahwa konsep pemasaran terdiri pemasaran tradisional termasuk $4 \mathrm{P}$ adalah Produck, Price, Place, dan Promotiom sedangkan untuk pemasaran jasa, diperlukan bauran pemasaran dengan penambahan unsur bauran pemasaran non-tradisional 3P'S , yaitu people, process, physical evidence. $3 \mathrm{P}$ dalam bauran pemasaran adalah elemen mendasar bagi sektor perbankan sebagai faktor yang selalu memberikan kontribusi bagi terciptanya kepuasan dan loyalitas nasabah.

\section{A.4. Process}

Proses sebagai kombinasi dari semua kegiatan, yang pada umumnya meliputi prosedur, mekanisme dan layanan sebagai keputusan, rencana, dilengkapi dengan anggapan tertentu (Ratnasari \& Mastuti, 2011). Proses, yaitu mode operasi atau rangkaian tindakan tertentu, biasanya berupa langkah-langkah yang diperlukan dalam urutan tertentu (Lovelock \& Wright, 2018). Proses juga berarti: semua prosedur yang berlaku, mekanisme dan kegiatan yang digunakan untuk memberikan layanan (Shafitranata, 2019).

Perusahaan perlu merancang layanan yang merupakan proses penyampaian yang unggul, tidak birokratis, dan berfokus pada pelanggan. Layanan tingkat tinggi melibatkan konsumen dalam proses pemberian layanan, sehingga konsumen tidak perlu tahu tentang peran mereka. Teknologi kini memiliki peran strategis dalam layanan online (Tjiptono F. , 2015). Perusahaan membuat dan mengirimkan produk, konsumen membutuhkan desain dan implementasi serta proses yang efektif. Proses menggambarkan bagaimana sistem operasi dan alur kerja. Proses yang dirancang dengan buruk, seperti layanan mereka yang lambat, birokratis, dan tidak efisien . Selain itu, pekerja garis depan yang berkinerja buruk, sehingga produktivitas rendah dan (Lovelock \& Wright, 2018) mencegah kemungkinan kesalahan tingkat pertama meningkat (Rosadi \& Dwi, 2018) berdasarkan indikator Proses: kecepatan transaksi dan transaksi terukur Pada penelitian ini, proses diukur dari Pelayanan cepat, Proses yang sesuai dengan harapan, Kesesuaian waktu pelayanan, dan Perasaan aman (Lovelock \& Wright, 2018)

Proses pelayanan merupakan faktor penting dalam bauran pemasaran jasa, karena pelanggan jasa suka melihat sistem penyampaian jasa sebagai bagian dari jasa. Prosesnya mudah dan cepat, seperti kesederhanaan pesan, transaksi dan kecepatan transaksi, kepuasan pelanggan dapat terpengaruh. Pandangan ini didukung oleh penelitian ( Lisarini, 2014, Fathoni, 2016, Astuti, 2017, Rosadi \& Dwi, 2018 dan Shafitranata, 2019) yang menekankan bahwa proses mempengaruhi kepuasan konsumen.

Layanan kepada konsumen dianggap sebagai hasil dari aktivitas logistik dan pemasaran distribusi Jasa Jasa untuk konsumen mencapai kepuasan. Layanan pelanggan mencakup aktivitas yang membutuhkan waktu untuk dibuat dan dikirimkan, termasuk layanan biaya perdagangan, perdaganganomto-la, dan pasca perdagangan. Kegiatan pra-transaksi (pre-transaction) juga mempengaruhi kegiatan transaksi dan pasca-transaksi, sehingga kegiatan pra-transaksi harus dapat ditanggapi secara positif oleh konsumen dan menunjukkan loyalitas yang baik. proses transaksi yang tinggi, seperti penggunaan pesanan, transaksi, dan kecepatan transaksi dapat mempengaruhi loyalitas pelanggan. Hal ini sejalan dengan penelitian (Samboro, 2009, Bahari \& Siaga, 2018, dan Hadinnisa, 2018) bahwa proses-proses tersebut mempengaruhi keterlibatan konsumen. Berdasarkan uraian tersebut dapat diambil asumsi sebagai berikut:

$\mathrm{H}: 1$ Process bengaruh terhadap kepuasan nasabah

$\mathrm{H}_{5:}$ Process pengaruh terhadap loyalitas nasabah 


\section{JESYN}

JURNAL EKONOMI \& EKONOMI SYARIAH

Jurnal Ekonomi \& Ekonomi Syariah Vol 5 No 1, Januari 2022

E-ISSN : 2599-3410 | P-ISSN : 2614-3259

DOI : https://doi.org/10.36778/jesya.v5i1.530

\section{A.5. People}

(Ratnasari \& Mastuti, 2011) adalah people atau nara sumber yang meliputi pegawai biasa dan pegawai fungsional organisasi. Kesemuanya itu merupakan faktor-faktor yang memiliki peran penting dalam penyajian pelayanan untuk mempengaruhi persepsi pembeli (Shafitranata, 2019). Mereka juga karyawan yang melayani pelanggan atau rencana layanan (Hadinnisa, 2018) Layanan pemasaran mempunyai unsur penyedia layanan yang berpengaruh kuat pada kualitas layanan yang diberikan. Maksudnya adalah agar karyawan yang sukses bisa menyenangkan konsumen (Tjiptono F. , 2011). Konsumen yang puas dapat melakukan aktivitas yang sama pada waktu yang berbeda atau tetap setia pada jasa yang ditawarkan oleh organisasi. Pelayanan dengan banyak fitur yang dikenal seperti kesopanan dan ramah dan terlihat karyawan yang rapi. Layanan tergantung pada interaksi langsung dan pribadi antara konsumen dan karyawan perusahaan. Sifat interaksi tersebut memiliki pengaruh yang besar terhadap konsumen mengenai kualitas pelayanan. Konsumen seringkali mengevaluasi kualitas layanan yang mereka terima berdasarkan fasilitas yang mereka berikan (Tjiptono F. , 2011)

Elemen manusia (People) adalah karyawan perusahaan, dan konsumen lainnya. Segala tindakan dan perilaku pegawai, pakaian pegawai dan tingkah laku pegawai mempengaruhi keberhasilan pelayanan (Shafitranata, 2019). (Rosadi \& Dwi, 2018) menyebutkan penggunaan indikator, sopan, ramah, dan kerapian penampilan. Menurut (Hurriyati, 2005) elemen manusia (People) diukur dengan kesantunan dan keramahan, mudah dihubungi, penampilan rapi dan pelayanan yang sesuai. Penampilan pribadi karyawan yang lebih baik, seperti sopan dan ramah, rendah hati, rapi, akan mempengaruhi kepuasan pelanggan. Pandangan tersebut didukung oleh beberapa risalah yang menyatakan bahwa people mempengaruhi kepuasan pelanggan (Putra \& Sulistyawati , 2013), (Noviana, 2013): (Astuti, 2017), (Setianingsih, 2017), (Rosadi \& Dwi, 2018); dan (Shafitranata, 2019).

People memiliki peran penting dalam keberhasilan perusahaan. People yang berhubungan langsung dengan konsumen sebagai bagian penting dari pelayanan yang menjadikan kepuasan dan loyalitas nasabah . Pengetahuan dan keterampilan People yang bekerja sesuai dengan tujuan bisnis sebagai aset yang sangat penting untuk kesuksesan (Grewal \& Levy, 2010). Hal ini sejalan dengan penelitian (Samboro, 2009), (Bahari \& Siaga, 2018) dan (Hadinnisa, 2018) yang menunjukkan bahwa People mempengaruhi loyalitas nasabah. . Berdasarkan informasi, hipotesis dapat dinyatakan sebagai berikut:

H2: People Pengaruh kepuasan Nasabah

H 6: People Pengaruh loyalitas Nasabah

\section{A.6. Physical Evidence}

Physical evidence adalah lingkungan tempat layanan bisnis yang dibuat dan penyedia layanan berinteraksi dengan klien juga merupakan elemen nyata dalam berkomunikasi atau mendukung peran layanan (Ratnasari \& Mastuti, 2011). physical evidence mencakup petunjuk visual berisi gambar atau isyarat nyata lainnya yang menunjukkan kualitas layanan (Lovelock \& Wright, 2018). Jadi, physical evidence adalah fakta yang juga mempengaruhi keputusan konsumen tentang membeli dan menggunakan produk atau jasa yang ditawarkan (Shafitranata, 2019). (Rosadi \& Dwi, 2018) menyatakan physical evidence terukur dari keamanan, kebersihan, dan parkir. 
Elemen dalam fasilitas fisik meliputi lingkungan atau bangunan, peralatan, peralatan, logo, warna dan elemen lainnya. physical evidence bangunan, sarana transportasi atau tempat parkir yang luas dapat mempengaruhi kepuasan pelanggan. Menurut (Hurriyati, 2005), indikator physical evidence meliputi: fisik bangunan yang menarik, alat uji, kepemilikan fasilitas fisik (meja, kursi, televisi, komputer, dll), tata letak/interior yang baik, dan ruang tunggu pelanggan yang nyaman. Pendapat ini sejalan dengan penelitian (Tjandra \& Panjaitan, 2008), (Sari, 2015), (Sanjaya \& Yuliastanty, 2016), (Astuti, 2017), (Setianingsih, 2017), (Rosadi \& Dwi, 2018)dan (Shafitranata, 2019), yang mengklaim bahwa physical evidence berdampak pada kepuasan konsumen.

(Hurriyati, 2005) memberikan physical evidence sebagai hal yang mempengaruhi keputusan pembelian konsumen dan konsumsi. Misalnya, dapat physical evidence mendukung loyalitas konsumen dalam suatu transaksi. Pandangan ini konsisten dengan penelitian (Samboro, 2009), (Bahari \& Siaga, 2018) dan (Hadinnisa, 2018) physical evidence memiliki efek secara signifikan terhadap loyalitas pelanggan. Berdasarkan keterangan tersebut, maka hipotesis dapat dinyatakan sebagai berikut

H3 : physical evidence berpengaruh terhadap Kepuasan Nasabah

$\mathrm{H} 7$ : physical evidence berpengaruh terhadap Loyalitas Nasabah

Berdasarkan pemikiran di atas, maka dapat digambarkan sebuah kerangka pemikiran teoritis seperti pada gambar 1 .

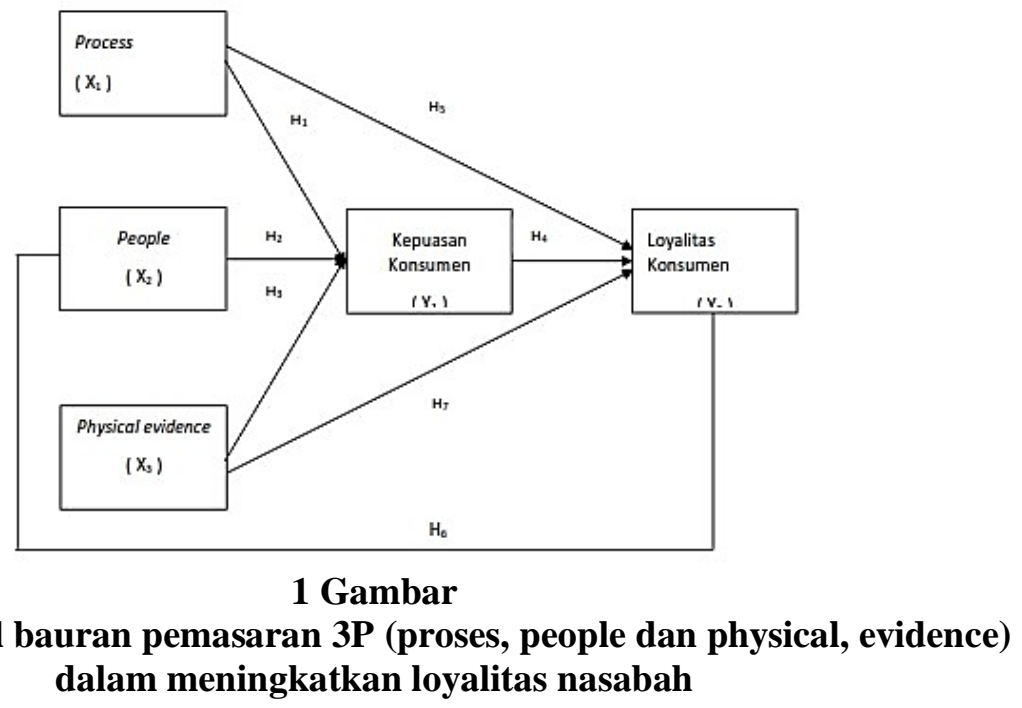

\section{METODE PENELITIAN}

Data dalam penelitian ini adalah data primer. Metode pengumpulan data menggunakan kuesioner dan wawancara mendalam, dikumpulkan melalui kuesioner yang dilakukan selama bulan Januari 2021. Populasi penelitian meliputi seluruh nasabah PT BPR BKK Demak (Perusda) yang pada Desember 2020 berjumlah 5.075 nasabah Jumlah sampel yang diambil 189 responden. Pengambilan sampel dalam penelitian ini dilakukan dengan menggunakan teknik random/acak, yaitu teknik pengambilan sampel yang memberikan kesempatan yang sama kepada setiap anggota masyarakat untuk dipilih menjadi anggota sampel (Siregar, 2017). Sedangkan jenis sampel acak yang 
dipilih ada dua yaitu, proportional random sampling dan Purpusive random sampling. Proportional random sampling. Kriteria pemilihannya adalah: responden merupakan nasabah BPR-BKK di Demak berusia 17 sampai dengan 60 tahun, sudah menjadi nasabah selama 2 tahun dan siap menjadi responden. Skala pengukuran Variabel menggunakan skala Likert dari 1 sampai 10, sangat tidak setuju (skala 1) hingga sangat setuju (skala 10). Ukuran loyalitas pelanggan diturunkan dari (Shafitranata, 2019), (Griffin, 2005)); Kepuasan Klien dari (Setianingsih, 2017), (Tjiptono F. , 2008); 3 P'S meliputi: Proses diperoleh (Lovelock \& Wright, 2018); People (Rosadi \& Dwi, 2018), (Hurriyati, 2005)); dan physical evidence (Hurriyati, 2005).

Selanjutnya untuk melakukan pengujian hipotesis menggunakan Analisis Jalur, Uji Intervening (Pengaruh Langsung dan Tidak Langsung) dengan Uji Sobel (Sobel Test).

Persamaan Sub Struktur I: $\mathrm{Z}=\mathrm{b}_{1} \mathrm{X}_{1}+\mathrm{b}_{2} \mathrm{X}_{2}+\mathrm{b}_{3} \mathrm{X}_{3}+e 1$

Persamaan Sub Struktur II: $\mathrm{Y}_{1}=\mathrm{b}_{1} \mathrm{X}_{1}+\mathrm{b}_{2} \mathrm{X}_{2}+{ }_{\mathrm{b} 2} \mathrm{X}_{2}+\mathrm{b}_{3} \mathrm{Z}+e 2$

Keterangan :

$\mathrm{Y}_{1}$ : Loyalitas konsumen $\quad \mathrm{X}_{3}:$ Physical Evidence

$B$ : Koefisien Regresi Z: Kepuasan Konsumen

$\mathrm{X}_{1}$ : Process

$e_{1, \mathrm{e} 2:}$ Residual

$\mathrm{X}_{2}$ :People

Hasil uji validitas dan reliabilitas adalah sebagai berikut.:

\section{Tabel 1}

Hasil Uji Validitas dan Reliabilitas

\begin{tabular}{|c|c|c|c|}
\hline Variabel & Indikator & $\begin{array}{c}\mathbf{r} \\
\text { hitung }\end{array}$ & $\begin{array}{c}\text { Cronbach's } \\
\text { Alpha }\end{array}$ \\
\hline \multicolumn{4}{|c|}{$\begin{array}{l}\text { Process } \mathbf{X}_{1} \text { adalah metode pengoperasian atau serangkaian tindakan tertentu yang } \\
\text { umumnya berupa langkah-langkah yang diperlukan dalam suatu urutan yang telah } \\
\text { ditetapkan }\end{array}$} \\
\hline & Pelayanan cepat. & 0,758 & \multirow[t]{4}{*}{0.904} \\
\hline & Proses yang sesuai dengan harapan & 0,795 & \\
\hline & Kesesuaian waktu pelayanan & 0,800 & \\
\hline & Perasaan aman & 0,795 & \\
\hline \multicolumn{4}{|c|}{$\begin{array}{l}\text { People }\left(\mathbf{X}_{2}\right) \text { atau sumber daya manusia adalah pegawai yang terlibat dalam proses } \\
\text { operasional organisasi }\end{array}$} \\
\hline & Kesopanan dan keramahan & 0,497 & \multirow[t]{4}{*}{0.757} \\
\hline & Kemampuan dalam pelayanan & 0,521 & \\
\hline & Penampilan rapi & 0,534 & \\
\hline & Pelayanan yang akurat & 0,520 & \\
\hline \multicolumn{4}{|c|}{$\begin{array}{l}\text { Physical Evidence }\left(\mathbf{X}_{3}\right) \text { adalah petunjuk visual atau berwujud lainnya yang memberi bukti } \\
\text { atas kualitas jasa }\end{array}$} \\
\hline & Bangunan fisik yang menarik & 0,644 & \multirow[t]{3}{*}{0.872} \\
\hline & Peralatan pemeriksaan yang menunjang & 0,789 & \\
\hline & Fasilitas fisik yang dimiliki & 0,797 & \\
\hline
\end{tabular}




\begin{tabular}{|c|l|c|c|}
\hline Variabel & Indikator & $\begin{array}{c}\text { r } \\
\text { hitung }\end{array}$ & $\begin{array}{c}\text { Cronbach's } \\
\text { Alpha }\end{array}$ \\
\hline & Tata ruang/Interior yang menarik & 0,739 & \\
\hline
\end{tabular}

Kepuasan Nasabah (Z) adalah perbandingan antara harapan atau ekspektasi sebelum pembelian dan persepsi terhadap kinerja setelah pembeli

\begin{tabular}{|l|c|}
\hline Reduksi sensitifitas harga. & 0,752 \\
\hline $\begin{array}{l}\text { Hubungan antara perusahaan dan pelanggan menjadi } \\
\text { harmonis. }\end{array}$ & 0,826 \\
\hline $\begin{array}{l}\text { Rekomendasi dari mulut ke mulut yang } \\
\text { menguntungkan Perusahaan }\end{array}$ & 0,841 \\
\hline Reputasi perusahaan menjadi baik dimata konsumen. & 0,829 \\
\hline
\end{tabular}

0.918

Loyalitas Nasabah $\left(\mathbf{Y}_{2}\right)$ adalah keputusan konsumen untuk secara suka rela terus
berlangganan dengan perusahaan tertentu dalam jangka waktu yang lama

\begin{tabular}{|l|c|c|}
\hline Melakukan pembelian ulang & 0,494 & \multirow{2}{*}{0.863} \\
\cline { 1 - 1 } Tidak beralih ke pesaing & 0,715 & \\
\cline { 1 - 2 } $\begin{array}{l}\text { Membicarakan hal-hal yang positif kepada people } \\
\text { lain }\end{array}$ & 0,800 & \\
\cline { 1 - 2 } Menyampaikan keluhan yang dirasakan & 0,734 & \\
\cline { 1 - 2 } Melakukan pembelaan & 0,683 & \\
\hline
\end{tabular}

Sumber: Data Primer Diolah, 2021

Berdasarkan korelasi antara jawaban responden untuk setiap pertanyaan dan total nilai jawaban responden pada setiap variabel, memberikan hasil yang signifikan dengan sig. 0,05. Artinya semua indikator di atas valid atau sudah benar. Sedangkan Hasil uji reliabilitas menggunakan Cronbach Alpha, diperoleh nilai alpha $(\alpha)$ dari setiap variabel lebih besar dari 07,0, dengan hasil ini indikator dari masing-masing variabel terbukti reliabel.

\section{HASIL PENELITIAN}

\section{A.1. Demografi Responden}

Karakteristik responden dalam penelitian ini disajikan dalam tablel sebagai berikut:

Tabel 2

Identitas Responden

\begin{tabular}{|c|c|c|c|c|c|c|c|}
\hline \multicolumn{2}{|c|}{ Keterangan } & Frekuensi & $(\%)$ & \multicolumn{2}{|c|}{ Keterangan } & Frekuensi & $(\%)$ \\
\hline \multirow{3}{*}{$\begin{array}{l}\text { Jenis } \\
\text { Kelamin }\end{array}$} & Perempuan & 102 & $54 \%$ & \multirow[t]{5}{*}{ Pendidikan } & SMP & 14 & $7.4 \%$ \\
\hline & Laki-laki & 87 & $46 \%$ & & SMA & 128 & $67.7 \%$ \\
\hline & Jumlah & 189 & $100 \%$ & & DIII & 12 & $6.4 \%$ \\
\hline \multirow[t]{7}{*}{ Umur } & $20-30$ & 57 & $30.2 \%$ & & Sarjana & 35 & $18.5 \%$ \\
\hline & $31-40$ & 86 & $45.5 \%$ & & Jumlah & 189 & $100 \%$ \\
\hline & $41-50$ & 46 & $24.3 \%$ & \multirow{5}{*}{$\begin{array}{l}\text { Lama } \\
\text { Menjadi } \\
\text { Nasabah }\end{array}$} & $2-3$ & 62 & $32.8 \%$ \\
\hline & \multirow[t]{4}{*}{ Jumlah } & \multirow[t]{4}{*}{189} & \multirow[t]{4}{*}{$100 \%$} & & $3,1-4$ & 54 & $28.6 \%$ \\
\hline & & & & & $4,1-5$ & 34 & $18.0 \%$ \\
\hline & & & & & $5,1-6$ & 39 & $20.6 \%$ \\
\hline & & & & & Jumlah & 189 & $100 \%$ \\
\hline
\end{tabular}

Sumber: Data Primer Yang Diolah, 2021

Berdasarkan tabel 2 menunjukkan bahwa dari 189 responden, seluruh nasabah BPR/BKK di Di Demak umumnya perempuan dengan jumlah 102 responden (54\%), dan sisanya adalah responden 


\section{JESYN}

JURNAL EKONOMI \& EKONOMI SYARIAH

Jurnal Ekonomi \& Ekonomi Syariah Vol 5 No 1, Januari 2022

E-ISSN : 2599-3410 | P-ISSN : 2614-3259

DOI : https://doi.org/10.36778/jesya.v5i1.530

laki-laki sebanyak 87 responden (46\%). Tingkat pendidikan tertinggi adalah SMA yaitu 128 responden $(67,7 \%)$. Pada saat pendataan di lapangan, sebagian responden termasuk pedagang dan industri rumahan, sehingga pasangan suami istri yang mengelola dan mengontrol keuangannya.

Berdasarkan usia responden, umumnya berusia 35-40 tahun dengan jumlah 86 people atau $45,5 \%, 30,2 \%$ berusia antara 20-30 tahun dan 24,3\% berusia 20 hingga 30 tahun lebih. Dengan lead time yang lama bagi pelanggan antara 2 sampai 3 tahun. Hal ini menunjukkan bahwa nasabah BPRBKK di Kabupaten Demak adalah usia produktif yang dapat mendukung kegiatan usaha atau membutuhkan modal untuk meningkatkan usahanya

\section{A.2. Uji Normal dan Asumsi Klasik}

Hasil uji normalitas menunjukkan nilai p yang besar (Asymp. Sig). diperoleh lebih besar dari 0,05 yaitu $(0,200>0,05)$. Artinya model regresi yang dibuat dalam penelitian biasanya berdistribusi, sehingga model regresi berguna dalam penelitian karena model regresi mengasumsikan asumsi normalitas.

Hasil uji multikolinearitas menunjukkan bahwa semua variabel independen memiliki nilai tolerance kurang dari 0,1 artinya tidak ada korelasi antar variabel independen yang nilainya lebih dari 95\%. Hasil perhitungan Variance Inflation Factor (VIF) juga menunjukkan hal yang sama jika tidak ada variabel independen yang memiliki nilai VIF tidak lebih dari 10. Artinya tidak terdapat multikolinearitas antar variabel independen dalam regresi model fesyen.

Hasil uji heteroskedastisitas menunjukkan bahwa nilai signifikansi masing-masing variabel bebas yang diperoleh lebih besar dari 0,05 (signifikansi > 0,05). Artinya model regresi yang digunakan dalam penelitian ini tidak menghasilkan heteroskedastisitas.

\section{A.3. Goodness Of Fit}

Model 1: Hasil koefisien determinasi sebesar 0,186 (18,6\%) artinya 3P marketing mix (proses, people, dan physical evidence )dapat menjelaskan kepuasan sebesar 18,6\%, dan sisanya $(81,4 \%)$ dijelaskan oleh variabel lain. F sebesar 14,098 dengan nilai Sig sebesar 0,000b. Nilai Sig yang diperoleh lebih kecil $(<0,05)$ sehingga model regresi 1 dapat digunakan untuk memprediksi variabel bebas dan model regresi yang digunakan fit atau Model 2: Koefisien determinasi model 2 adalah 0,449 (44,9\%), yang berarti 3P marketing mix dan kepuasan nasabah dapat menjelaskan loyalitas nasabah sebesar 44,9\%, sedangkan sisanya $(55,1 \%)$ dijelaskan oleh variabel lain. Hasil uji $\mathrm{F}$ adalah 37,412, Sig 0,000. Hal ini berarti model 2 regresi dapat digunakan untuk memprediksi variabel dependen karena nilai Sig. lebih kecil $(<0,05)$, sehingga kedua model tersebut adalah fit.

\section{A.4. Pengujian Hipotesis}

Uji hipotesis dari membangun loyalitas nasabah melalui 3 P'S Marketing mix, dengan kepuasan nasabah sebagai variabel mediasi berpengaruh positif dan signifikan, artinya bila 3 P'S Marketing mix (process, people, dan physichal evindance) ditingkatkan, maka kepuasan nasabah akan meningkat, dan nasabah menjadi loyal atau tidak berpindah ke bank lain sehingga akan terbangun loyalitas nasabah . Hasil uji hipotesis t dapat dilihat pada tabel berikut ini:

Tabel 3 


\section{Uji-t test}

\begin{tabular}{|l|c|c|}
\hline \multicolumn{1}{|c|}{ Pengaruh Variabel } & t & Sig. \\
\hline 1. (Constant) & 5.192 & 0.000 \\
\hline Proses $\left(\mathrm{X}_{1}\right) \rightarrow \mathrm{Z}$ & 2.387 & 0.018 \\
\hline People $\left(\mathrm{X}_{2}\right) \rightarrow \mathrm{Z}$ & 3.389 & 0.001 \\
\hline Physical Evidence $\left(\mathrm{X}_{3}\right) \rightarrow \mathrm{Z}$ & 2.232 & 0.027 \\
\hline 2. (Constant) & 3.141 & 0.002 \\
\hline Proses $(\mathrm{X} 1) \rightarrow \mathrm{Y}$ & 4.840 & 0.000 \\
\hline People $(\mathrm{X} 2) \rightarrow \mathrm{Y}$ & 2.715 & 0.007 \\
\hline Physical Evidence $(\mathrm{X} 3) \rightarrow \mathrm{Y}$ & 3.224 & 0.001 \\
\hline Kepuasan Nasabah $(\mathrm{Z}) \rightarrow \mathrm{Y}$ & 4.557 & 0.000 \\
\hline
\end{tabular}

1. Dependent Variable $Z$

2. Dependent Variable $Y$

Sumber: Data Primer yang Diolah (2021)

\section{Model 1:}

Pengujian hipotesis pengaruh process terhadap kepuasan nasabah, diperoleh nilai uji t sebesar 2.387 dengan nilai Sig. 0.018. Nilai Sig. lebih kecil $(<0,05)$ sehingga menerima hipotesis yang menyatakan proses berpengaruh terhadap kepuasan nasabah, dengan demikian semakin baik process pelayanan yang diberikan bank, maka semakin memberikan kepuasan pada nasabahnya. Hasil penelitian ini didukung (Lisarini, 2014), (Fathoni, 2016), (Astuti, 2017); (Rosadi \& Dwi, 2018); serta (Shafitranata, 2019), yang menyatakan bahwa proses berpengaruh terhadap kepuasan konsumen.

Pengujian hipotesis pengaruh people terhadap kepuasan nasabah, diperoleh nilai uji t sebesar 3.389 dengan nilai Sig. 0.001 sehingga menerima hipotesis yang menyatakan people berpengaruh terhadap kepuasan nasabah. Artinya semakin baik people dalam berinteraksi langsung dengan nasabahnya maka akan meningkatkan kepuasan dari nasabahnya. Hasil penelitian mendukung hasil penelitian (Putra \& Sulistyawati , 2013), (Noviana, 2013), (Astuti, 2017), (Setianingsih, 2017), (Rosadi \& Dwi, 2018) serta (Shafitranata, 2019) yang menyatakan bahwa people berpengaruh terhadap kepuasan konsumen.

Pengujian hipotesis pengaruh Physical Evidence terhadap kepuasan nasabah, didapatkan nilai uji t sebesar 2.232 dengan nilai Sig. 0.027 ssehingga menerima hipotesis yang menyatakan Physical Evidence berpengaruh terhadap kepuasan nasabah. Artinya semakin bagus dan lengkap Physical Evidence yang dimiliki bank, maka tingkat kepuasan nasabah akan meningkat. Hasil penelitian ini mendukung hasil penelitian (Sari, 2015), (Tjandra \& Panjaitan, 2008), (Sanjaya \& Yuliastanty, 2016), (Astuti, 2017), (Setianingsih, 2017), (Rosadi \& Dwi, 2018) serta (Shafitranata, 2019) yang menyatakan bahwa physical evidence berpengaruh terhadap kepuasan konsumen.

\section{Model 2:}

Pengujian hipotesis pengaruh proses terhadap loyalitas nasabah diperoleh hasil uji t sebesar 4,840 dengan sig. 0,000 < 0,05, dengan demikian menerima hipotesis bahwa proses berpengaruh positif dan signifikan terhadap loyalitas nasabah. Artinya, nasabah yang mendapatkan proses pelayanan lebih mudah atau mendapatkan prioritas, maka mereka akan lebih loyal. Pendapat ini mendukung hasil penelitian (Bahari \& Siaga, 2018) dan (Hadinnisa, 2018) yang menegaskan bahwa proses mempengaruhi loyalitas konsumen 
Hipotesis People berpengaruh terhadap loyalitas nasabah, membuktikan t 2,715 dan sig. 0,007< 0,05 . Sehingga hipotesis yang menyatakan bahwa ada pengaruh positif antara People terhadap loyalitas diterima. Sehingga karyawan yang memiliki sikap lebih peduli dan mau terus berkomunikasi dengan nasabah akan meningkatkan rasa loyalitas nasabah untuk menggunakan jasa BPR BKK Demak. Hasil penelitian ini mendukung hasil penelitian (Bahari \& Siaga, 2018) dan (Hadinnisa, 2018) yang menegaskan bahwa people mempengaruhi loyalitas konsumen.

Uji hipotesis pengaruh physical evidence terhadap loyalitas nasabah, diperoleh hasil uji t 3,224 dengan nilai dan sig. 0,001 $<0,005$, maka hipotesis bahwa terdapat pengaruh positif antara Physical Evidence terhadap loyalitas nasabah bank diterima. Artinya dengan menyediakan sarana dan prasarana yang dapat digunakan dengan baik oleh setiap nasabah yang datang menggunakan jasa, hal ini merupakan bukti kualitas pelayanan yang baik dan akan menciptakan loyalitas nasabah untuk dapat menggunakan jasa tersebut. Penelitian ini didukung oleh hasil penelitian (Bahari \& Siaga, 2018) dan (Hadinnisa, 2018) yang menegaskan bahwa physical evidence berpengaruh terhadap loyalitas konsumen.

Uji hipotesis pengaruh kepuasan pelanggan terhadap loyalitas nasabah, diperoleh hasil uji $\mathrm{t}=$ 4,557 dengan nilai Sig. 0,000. Artinya hipotesis yang menyatakan bahwa ada pengaruh antara kepuasan dan loyalitas nasabah diterima karena nilai Sig. lebih kecil $(<0,05)$. Artinya, semakin puas nasabah, semakin loyal nasabah. Penelitian ini mendukung hasil penelitian (Simamora, 2007), (Al Afifah, 2016), (Sanjaya \& Yuliastanty, 2016) dan (Shafitranata, 2019) yang menegaskan bahwa kepuasan konsumen berpengaruh terhadap loyalitas konsumen.

Hasil Perhitungan uji efek mediasi dapat dibuat tabel 4

Tabel 4

Hasil Uji Efek Mediasi

\begin{tabular}{|c|c|c|c|c|}
\hline \multirow{2}{*}{ Variabel } & \multicolumn{2}{|l|}{ Pengaruh Langsung } & Pengaruh Tidak Langsung & $\begin{array}{c}\text { Pengaruh } \\
\text { Melalui Z }(\mathbf{Z x Y})\end{array}$ \\
\cline { 2 - 4 } & $\mathbf{Z}$ & $\mathbf{Y}$ & $0.187 \times 0.277=\mathbf{0 , 0 5 2}$ & 0,370 \\
\hline $\mathrm{X} 1$ & 0.187 & 0.318 & $0.252 \times 0.277=0,069$ & 0,241 \\
\hline $\mathrm{X} 2$ & 0.252 & 0.172 & $0.157 \times 0.277-0,043$ & 0,233 \\
\hline $\mathrm{X} 3$ & 0.157 & 0.190 & & 0,844 \\
\hline $\mathrm{Z}$ & & 0.277 & 0,156 \\
\hline
\end{tabular}

Data hasil uji pengaruh mediasi di atas menggambarkan:

Pengujian efek mediasi pengaruh tidak langsung proses terhadap loyalitas pelanggan melalui kepuasan nasabah $(0,052)$ lebih kecil dari pengaruh langsung proses terhadap loyalitas nasabah $(0,318)$, maka Kepuasan nasabah merupakan variabel mediasi dari variabel pengaruh proses terhadap Loyalitas. Hasil uji pengaruh mediasi membuktikan bahwa Proses berpengaruh positif dan signifikan terhadap loyalitas melalui kepuasan pelanggan. Penelitian ini sejalan dengan penelitian (Fathoni, 2016) yang menyatakan bahwa pengujian secara parsial atau simultan terhadap variabel proses kepuasan dan konsisten dengan penelitian yang dilakukan oleh (Lisarini, 2014) bahwa pengujian secara parsial atau simultan terhadap variabel proses kepuasan terbukti penting 
Efek tidak langsung people terhadap loyalitas pelanggan melalui kepuasan nasabah $(0,069)$ lebih kecil dari pengaruh langsung loyalitas nasabah $(0,172)$, mulai Kepuasan nasabah sebagai variabel mediasi pengaruh dalam Loyalitas nasabah. Hasil uji pengaruh mediasi membuktikan bahwa people mempengaruhi loyalitas konsumen melalui kepuasan nasabah sebagai variabel intervensi. Hasil penelitian mendukung hasil penelitian (Shafitranata, 2019) yang membuktikan bahwa people mempengaruhi loyalitas konsumen melalui kepuasan konsumen sebagai variabel intervensi.

Pengaruh tidak langsung Physical evidence terhadap loyalitas nasabah melalui kepuasan nasabah $(0,043)$ lebih kecil daripada pengaruh langsung Physical evidence terhadap loyalita nasabah (0,190), maka Kepuasan nasabah merupakan variabel mediasi pengaruh variabel Physical evidence terhadap Loyalitas. Hasil uji pengaruh mediasi membuktikan bahwa Physical Evidence berpengaruh terhadap loyalitas nasabah melalui kepuasan nasabah sebagai variabel intervening. Hasil penelitian mendukung hasil penelitian (Shafitranata, 2019) yang membuktikan bahwa Physical evidence mempengaruhi loyalitas melalui kepuasan pelanggan sebagai variabel intervening.

Gambar uji efek mediasi dari meningkatkan loyalitas nasabah melalui 3P'S marketing mix (process, people dan Physical Evidence) dilihat pada gambar.2

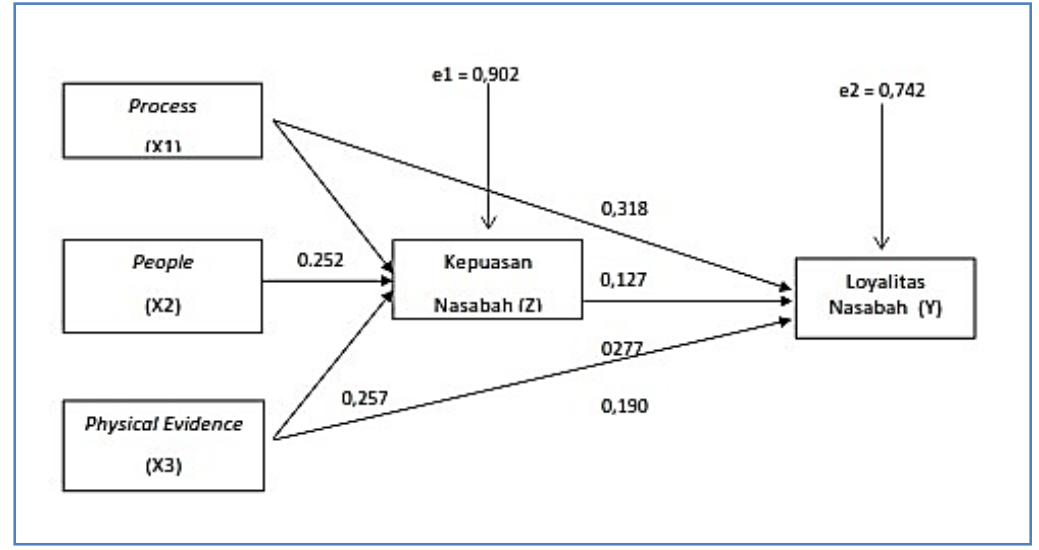

Gambar 2.

Efek Mediasi 3P'S Marketing Mix Dalam Meningkatkan Loyalitas Nasabah Bank

\section{A.5. Pembahasan}

Hasil penelitian pengaruh Bauran Pemasaran $3 \mathrm{P}$ (Process, People dan Physical evidence) dalam upaya meningkatkan loyalitas nasabah bank RB - BKK terbukti signifikan, sehingga menguatkan teori dan dapat memberikan dukungan terhadap penelitian sebelumnya. Temuan ini mendukung penelitian (Fathoni, 2016) yang menunjukkan pengujian parsial atau simultan variabel proses kepuasan dan konsisten dengan penelitian sebelumnya (Lisarini, 2014) bahwa pengujian parsial dan simultan variabel proses kepuasan terbukti signifikan, (Shafitranata, 2019) membuktikan bahwa physical evidence mempengaruhi loyalitas konsumen melalui kepuasan pelanggan sebagai variabel intervening (Shafitranata, 2019). (Umar, 2003), menekankan bahwa pelanggan yang puas dengan nilai suatu produk atau jasa dapat tetap setia untuk waktu yang lama. (Robbins \& Judge, 2013) 


\section{JESYN}

JURNAL EKONOMI \& EKONOMI SYARIAH

Jurnal Ekonomi \& Ekonomi Syariah Vol 5 No 1, Januari 2022

E-ISSN : 2599-3410 | P-ISSN : 2614-3259

DOI : https://doi.org/10.36778/jesya.v5i1.530

menjelaskan bahwa loyalitas memiliki tiga komponen, yaitu kognisi/evaluasi, afeksi/perasaan dan tindakan/perilaku.Hasil uji hipotesis, juga didukung oleh hasil uji pengaruh mediasi terhadap membangun loyalitas melalui perpaduan P3 Pemasaran dan kepuasan pelanggan sebagai media mediator, pertimbangkan hipotesis berikut:

Pengaruh tidak langsung proses terhadap loyalitas pelanggan melalui kepuasan pelanggan lebih kecil daripada pengaruh langsung proses terhadap loyalitas pelanggan, yaitu. Dalam suatu layanan perbankan yang berkualitas, proses merupakan faktor yang sangat penting, karena proses tersebut menyangkut berbagai hal, mulai dari nasabah mendaftar hingga mendapatkan layanan. Kondisi tersebut tentunya mempengaruhi kepuasan pelanggan. Temuan ini sesuai dengan penjelasan (Hurriyati, 2005) bahwa proses in-service merupakan faktor penting dalam bauran pemasaran layanan, karena pelanggan layanan akan sering menikmati sistem layanan. Penyampaian layanan yang sebenarnya menentukan tahap pengalaman pelanggan, meskipun alur proses layanan dapat digunakan sebagai bukti yang dapat dievaluasi oleh pelanggan. Pendapat ini didukung oleh (Lovelock \& Wright, 2018) yang menyatakan bahwa pemasar perlu memahami proses aktual pelanggan mereka. Ketika proses transaksi yang dilakukan konsumen sangat sederhana, dan tidak membuang waktu, pikiran, dan tenaga, konsumen akan merasa puas, bahkan loyal.

Hasil penelitian pengaruh Bauran Pemasaran 3 P (Process, People dan Physical evidence) dalam upaya kepatuhan loyalitas nasabah bank RB - BKK terbukti signifikan, sehingga menguatkan teori dan dapat memberikan dukungan terhadap penelitian sebelumnya. Temuan ini mendukung penelitian (Fathoni, 2016) yang menunjukkan pengujian parsial atau simultan variabel proses kepuasan dan konsisten dengan penelitian sebelumnya (Lisarini, 2014) bahwa pengujian parsial dan simultan variabel proses kepuasan terbukti signifikan, (Shafitranata, 2019) membuktikan bahwa fisik bukti yang mempengaruhi loyalitas konsumen melalui kepuasan pelanggan sebagai variabel intervening, dan (Shafitranata, 2019). (Umar, 2003), menekankan bahwa pelanggan yang puas dengan nilai yang diberikan oleh suatu produk atau jasa mungkin akan loyal untuk waktu yang lama. (Robbins \& Judge, 2013) menjelaskan bahwa skandal terbentuk dari tiga komponen yaitu, kognitif/evaluasi, afektif/perasaan dan tindakan/perilaku..

Hasil uji hipotesis secara parsial diatas, didukung oleh hasil hasil uji efek mediasi dari meningkatkan loyalitas melalui 3P marketing mix dengan kepuasan nasabah sebagai media mediator, uji hipotesis berikut:

Pengaruh tidak langsung proses terhadap loyalitas nasabah melalui kepuasan nasabah lebih kecil dibandingkan pengaruh langsung proses terhadap loyalitas nasabah, yaitu pada layanan perbankan yang berkualitas tinggi, proses merupakan faktor yang sangat penting karena prosesnya menyangkut hal yang berbeda, mulai dari pendaftaran nasabah. untuk menerima Layanan. Kondisi ini tentunya berdampak pada kepuasan pelanggan. Temuan ini sesuai dengan apa yang telah dijelaskan (Hurriyati, 2005) bahwa proses in-service merupakan faktor penting dalam bauran pemasaran-layanan, karena nasabah akan sering menikmati sistem layanan. Penyampaian layanan yang sebenarnya menentukan tahap pengalaman pelanggan, meskipun alur proses layanan dapat digunakan sebagai bukti yang dapat dievaluasi oleh pelanggan. Pendapat ini didukung oleh (Lovelock \& Wright, 2018) yang menyatakan bahwa pemasar perlu memahami proses aktual pelanggan mereka. Ketika proses transaksi yang dilakukan konsumen sangat sederhana, dan tidak membuang waktu, pikiran, dan tenaga, konsumen akan merasa puas, bahkan loyal.

Pengaruh tidak langsung terhadap loyalitas pelanggan melalui kepuasan pelanggan jauh lebih kecil daripada pengaruh langsung terhadap loyalitas pelanggan. Temuan ini tentu mendorong dukungan (Tjiptono F. , 2008) bahwa keterampilan karyawan merupakan elemen penting dalam 


\section{JESYN}

JURNAL EKONOMI \& EKONOMI SYARIAH

Jurnal Ekonomi \& Ekonomi Syariah Vol 5 No 1, Januari 2022

E-ISSN : 2599-3410 | P-ISSN : 2614-3259

DOI : https://doi.org/10.36778/jesya.v5i1.530

bauran pemasaran, karena dalam industri jasa semua karyawan adalah "pemasar paruh waktu". Setiap organisasi jasa dengan tingkat kontak pelanggan yang tinggi harus jelas tentang apa yang diharapkan dari setiap karyawan ketika berhadapan dengan pelanggan mereka. Menurut (Hurriyati, 2005), segala tindakan dan perilaku karyawan, bahkan pakaian dan penampilan karyawan, berdampak pada persepsi konsumen atau keberhasilan pemberian layanan (service counter). Dua penjelasan di atas menunjukkan bahwa dalam pelayanan perbankan, people memegang peranan penting dalam menunjang kepuasan nasabah. Klaim ini sesuai dengan pendapat (Grewal \& Levy, 2010) bahwa ketika memberikan layanan, mereka berkomunikasi langsung dengan konsumen, yang merupakan bagian penting dalam menciptakan kepuasan, bahkan loyalitas. Pendapat ini juga sependapat dengan pendapat tersebut (Hurriyati, 2005), jika pelayanan dilihat dari pelayanan yang baik, cepat, ramah, akurat dan lengkap, dapat menciptakan kepuasan dan loyalitas pelanggan kepada perusahaan yang pada akhirnya meningkatkan kinerja perusahaan. .

Pengaruh tidak langsung physical evidence terhadap loyalitas pelanggan melalui kepuasan pelanggan lebih kecil daripada pengaruh langsung physical evidence terhadap loyalitas pelanggan. Hasil penelitian menunjukkan bahwa physical evidence yang cukup, baik dari segi kecanggihan, kebersihan dan kelengkapan, sangat penting bagi kualitas layanan perbankan. Kondisi tersebut turut menentukan kualitas layanan yang diberikan oleh bank. Pendapat ini sejalan dengan pendapat (Yazit, 2005) yang menyatakan bahwa pelayanan tidak dapat diwujudkan sehingga sulit untuk dievaluasi, sehingga physical evidence memberikan indikasi seperti kualitas pelayanan. Sementara itu, (Lupiyoadi, 2001) berpendapat bahwa fasilitas fisik merupakan salah satu aspek yang menentukan kepuasan pelanggan. Pelanggan yang puas menunjukkan kemungkinan untuk membeli produk yang sama lagi. Dan pelanggan yang puas biasanya setia. (Lovelock \& Wright, 2018) berpendapat bahwa perusahaan jasa membedakan diri dari pesaing dan menciptakan fasilitas fisik untuk menarik pelanggan dari target pasar mereka. Klaim tersebut secara implisit menyatakan bahwa physical evidence yang baik merupakan upaya untuk meningkatkan kepuasan pelanggan

Kepuasan pelanggan mempengaruhi loyalitas pelanggan, pelanggan lebih puas dengan layanan, loyalitas akan meningkat. Pendapat ini didukung (Tjiptono F. , 2008) yang berpendapat bahwa loyalitas konsumen adalah kondisi ideal yang diharapkan oleh pemasar, bahwa konsumen memiliki sikap positif terhadap produk atau produsen dan disertai dengan pola pembelian berulang yang konsisten. Sementara kepuasan pelanggan adalah komponen penting dari loyalitas, itu adalah salah satu faktor yang menentukan apakah pelanggan potensial tetap setia atau bertaruh pada kesempatan pertama (Denove \& Power , 2007). tercipta ketika suatu perusahaan dapat menawarkan produk atau jasa yang dapat memenuhi harapan pelanggan dan memuaskan pelanggan; jika kepuasan pelanggan dapat diciptakan maka akan tercipta dan terciptanya pelanggan yang loyal.

\section{Simpulan}

Hasil analisis penelitian mendukung pemahaman bahwa 3 P'S marketing mix (proses, people dan physical evidence) berpengaruh positif terhadap upaya peningkatan loyalitas nasabah melalui kepuasan nasabah sebagai variabel intervening. Artinya dimensi variabel 3 P'S marketing mix mampu menjelaskan pengaruhnya dalam meningkatkan loyalitas nasabah bagi nasabah bank BPRBKK (Perusda), dengan kepuasan pelanggan untuk mendapatkan pelayanan adalah kunci sukses untuk menciptakan loyalitas dan menciptakan hubungan jangka panjang.

Kepuasan pelanggan adalah indikator terpenting dari loyalitas pelanggan. Nasabah yang merasa puas dengan layanan perbankan akan mengubah perasaan loyalitas dengan berbelanja lebih konsisten 
dan menasihati people lain untuk membeli produk dan layanan perbankan. Bank BPR - BKK (Perusda) sebagai salah satu lembaga di bidang jasa harus meningkatkan dan mengoptimalkan bauran pemasaran melalui 3P agar tercipta loyalitas nasabah. Nasabah yang merasa nyaman dan aman serta sadar akan kebutuhan dan kesesuaian bank akan mengalami kepuasan yang bermuara pada loyalitas, sehingga dapat dikatakan persepsi/evaluasi nasabah terhadap bauran pemasaran 3 P'S yang diberikan oleh Bank akan menimbulkan rasa kepuasan/kognitif yang akan menentukan loyalitas. Jika pelanggan merekomendasikan pada nasabah dan membeli kembali, maka pelanggan dapat disebut mempunyai loyalitas.

Implikasi manajerial dalam penelitian ini adalah pentingnya menciptakan loyalitas nasabah melalui bauran pemasaran 3 P'S, tidak hanya untuk mendatangkan nasabah lama yang pasti melakukan transaksi kembali di bank, tetapi juga memberikan nilai tambah kepada nasabah melalui berbagai cara yang bersumber dari berbagai sumber. nasabah, bank harus memenuhi dan melampaui harapan nasabah. Bank harus mampu menyediakan lebih dari kebutuhan dasar nasabah agar nasabah merasa nyaman menjadi nasabah yang loyal. Bank juga perlu menjaga dan meningkatkan pelayanan, baik dalam pelayanan yang diberikan oleh karyawan, dalam memproses, dan meningkatkan penyediaan physical, evidence secara konsisten untuk meningkatkan loyalitas.

Keterbatasan penelitian ini meliputi metode penelitian yang menggunakan cross sectional, sehingga tidak memperhitungkan time-lags dalam hubungan antar variabel. Penelitian kedepan dibutuhkan pendekatan yang dapat memberikan lebih banyak bukti tentang upaya yang dapat dilakukan bank untuk menciptakan loyalitas bagi nasabah bank.

\section{REFERENSI}

Aaker, D. (2013). Manajemen Pemasaaran Strategis. Jakarta: Salemba Empat.

Adhamovna, B. G. (2016). Banking Competition and Stability: Comprehensive Literature Review. International Journal of Management Science and Business Administration, 2(6), 26-33.

Al Afifah, A. (2016). Pengaruh Kualitas Layanan, Kepercayaan, Dan Kepuasan Terhadap Loyalitas Nasabah (Studi Kasus di PT Bank Syariah Mandiri Kantor Cabang Simpang Patal Palembang). Pelembang: UIN Raden Fatah.

Alma, B. (2013). Manajemen Pemasaran dan Pemasaran Jasa. Bandung: Alfabeta.

Astuti, D. L. (2017). Pengaruh Bauran Pemasaran Jasa Terhadap Kepuasan Penumpang Kereta Api Serayu. Ekonomi, Bisnis \& Entrepreneurship, 11(2), 123 - 136.

Bahari, C., \& Siaga, A. (2018). Pengaruh Strategi Bauran Pemasaran Terhadap Loyalitas Pasien Di Rumah Sakit Petrokimia Gresik. Jurnal Gema Ekonomi, 7(1), 10 - 27.

Denove, C., \& Power , J. (2007). Satisfaction. (R. Ponziani, Penerj.) Jakarta: PT Elex Media Komputindo.

Ellena, F. (2011). Analisis Pengaruh Kepercayaan, Komitmen, Komunikasi, dan Penanganan Keluhan terhadap Loyalitas Nasabah (Studi pada Nasabah PT. BRI (Persero) Tbk. Cabang Pemalang). Jurnal Manajemen, 1(1), 1-10. 
Jurnal Ekonomi \& Ekonomi Syariah Vol 5 No 1, Januari 2022

E-ISSN : 2599-3410 | P-ISSN : 2614-3259

DOI : https://doi.org/10.36778/jesya.v5i1.530

Farida, I. d. (2016). Analisis Pengaruh Bauran Pemasaran 7P Terhadap Kepuasan Pelanggan Pengguna Gojek Online. Jurnal Riset Manajemen dan Bisnis, 31-40.

Fathoni. ( 2016). Pengaruh Proses (Process), People (People), Dan Physical, evidence (Physical Evidence) Terhadap Kepuasan Pasien Di Klinik Utama Graha Medika Salatiga. Salatiga: STIE "AMA”.

Grewal, D., \& Levy, M. (2010). Marketing 2nd edition. New York.: McGraw Hill.

Griffin, J. ( 2005). Customer Loyality Menumbuhkan dan Mempertahankan kesetian Pelanggan. . Jakarta: Erlangga.

Hadinnisa, I. I. (2018). Pengaruh Bauran Pemasaran Jasa Terhadap Loyalitas Nasabah Tabungan Simpedes Bank BRI Kantor Unit Simpang Haru Padang. Jurnal STIE Perbankan Indonesia, l(1), $17-27$.

Haryanto, E. (2013). Kualitas Layanan, Fasilitas dan Harga Pengaruhnya terhadap Kepuasan Pengguna Jasa Layanan Pada Kantor Samsat Manado. Jurnal Ekonomi Manajemen dan Bisnis Akuntansi, 750 - 760.

Hurriyati, R. ( 2005). Bauran Pemasaran dan Loyalitas Konsumen. Bandung: Alfabeta.

Koskela E, Stenback R. (2000) Is there tradeoff between bank competition and financial frgility. $J$ Ban \& Fina ;24:1853-187

Kotler, P. ( 2000). Manajemen Pemasaran di Indonesia: Analisis, Perencanaan, implementasi, dan pengendalian. Jakarta: Salemba Empat.

Kotler, P., \& Keller, K. (2014). Manajemen Pemasaran. Jakarta: Erlangga.

Lisarini, E. d. (2014). Pengaruh Bauran Pemasaran 7P Terhadap Kepuasan Pelanggan Di Sweetberry Agrowisata Cipanas. Jurnal Agroscience.

Lovelock, C., \& Wright, L. (2018). Manajemen Pemasaran Jasa. Cetakan III. Jakarta: Indeks.

Lupiyoadi, R. (2001). Manajemen Pemasaran Jasa. Jakarta: Salemba Empat.

Masitha, Dwi dan Zaini, Achmad (2018) Pengaruh People, Process Dan Physical Evidence Terhadap Kepuasan Pelanggan Di Spencer Salon Cabang Soekarno Hatta Malang, Jurnal Aplikasi Bisnis.

Maulana. (2010). Pengaruh Kualitas Pelayanan, Kepuasan Dan Citra Terhadap Loyalitas Pasien Pada Rumah Sakit Syarif Hidayatullah Jakarta (Studi Kasus Mahasiswa UIN Jakarta Pasien Rawat Jalan Poli Umum). Jakarta: UIN Syarif Hidayatullah.

Nugroho, Ryan dan Japarianto, Edwin (2013) Pengaruh People, Physical Evidence, Product, Promotion, Price Dan Place Terhadap Tingkat Kunjungan Di Kafe Coffee Cozies Surabaya, Jurnal Manajemen Pemasaran Petra Vol. 1, No. 2

Noviana, B. I. (2013). Pengaruh Service Marketing Mix Terhadap Kepuasan Konsumen Hotel Amaris Surabaya. Jurnal Fakultas Ekonomi, Universitas Kristen Petra, Surabaya, 472-482.

Peter, J., \& Jerry , C. (2014). Perilaku Konsumen dan Strategi Pemasaran. Buku 2.Edisi 9. Jakarta: Salemba Empat. 
Jurnal Ekonomi \& Ekonomi Syariah Vol 5 No 1, Januari 2022

E-ISSN : 2599-3410 | P-ISSN : 2614-3259

DOI : https://doi.org/10.36778/jesya.v5i1.530

Putra, A., \& Sulistyawati , E. (2013). Pengaruh Bauran Pemasaran Jasa Terhadap Kepuasan Dan Loyalitas Nasabah PT. Pegadaian (Persero) Cabang Mengwi, Badung, Bali. Jurnal Ekonomi dan Bisnis, Universitas Udayana, Bali, 938-955.

Ratnasari, R., \& Mastuti, A. (2011). Manajemen Pemasaran Jasa. Bogor: Ghalia Indonesia.

Robbins , S., \& Judge, T. (2013). Organizational Behavior Edition 15. New Jersey: Pearson Education.

Rosadi , A., \& Dwi, G. (2018). Pengaruh Bauran Pemasaran Jasa Terhadap Strategi Kepuasan Pelanggan Pada Niki Sae Building Bogor. Jurnal Visionida., 1 - 12.

Samboro, J. (2009). Pengaruh People, Process, dan Physicahl Evidance Terhadap Loyalitas Melalui Keputusan Mahasiswa Memilih Politeknik Negeri Malang. Jurnal Pascasarjana Universitas Brawijaya, Malang.

Sanjaya, S., \& Yuliastanty, S. (2016). Pengaruh Bauran Pemasaran Jasa Terhadap Loyalitas Nasabah Dengan Kepuasan Atas Pelayanan Sebagai Variabel Intervening Pada Bank Rakyat Indonesia Unit Kuranji. Jurnal Ilmiah UPI YPTK, 39 -58.

Sari, M. (2015). Pengaruh Physical Evidence Terhadap Kepuasan Pelanggan Lottemart Dengan Aksebilitas Sebagai Variabel Moderator. Jurnal Ilmu dan Riset Manajemen.

Setianingsih, W. E. (2017). Pengaruh Bauran Pemasaran Jasa Terhadap Kepuasan Konsumen Pada Pondok Angkringan Kang Teek Jember. Jurnal Manajemen Dan Bisnis Indonesia, 18-30.

Setiyawati, A. (2009). Studi Kepuasan Pelanggan Untuk Mencapai Loyalitas Pelanggan (Studi Kasus Pada Konsumen Toko Bangunan Bangun Rejeki Semarang). Semarang : Undip.

Shafitranata. (2019). Pengaruh Bauran Pemasaran Jasa Terhadap Kepuasan Dan Loyalitas Nasabah Kredit Mikro PT. Bank BJB Bandar Lampung. Jurnal Ilmiah Mahasiswa Ekonomi Manajemen, 362 - 374.

Simamora, H. (2007). Manajemen Sumber Daya Manusia. Yogyakarta: STIE YKPN. .

Siregar, S. (2017). Metode Penelitian Kuantitatif : Dilengkapi Perhitungan Manual \& SPSS. Edisi Pertama. Cetakan ke 4. Jakarta : Kencana Prenada Media Group.

Soelasih, Y. (2016). Pengaruh Experiential Marketingdan Citra Merek Terhadap Kepuasan Penumpang Kereta Api Bisnis. Jurnal Ilmiah Manajemen.

Tjandra, S., \& Panjaitan, T. (2008). Faktor-Faktor Yang Mempengaruhi Kepuasan Konsumen Siloam Hospital Lippo Karawaci. DeReMa. Jurnal Manajemen.

Tjiptono, F. (2008). Perspektif Manajemen dan Pemasaran Kontemporer. Yogyakarta : Penerbit Andi.

Tjiptono, F. (2011). Pemasaran Jasa. Yogyakarta : Bayumedia Publishing.

Tjiptono, F. (2015). Strategi Pemasaran. Yogyakarta: Andi.

Tjiptono, F., \& Chandra, G. (2004). Service quality and satisfaction. Yogyakarta: Andi Offset.

Transtrianingzah, F. (2006). Analisis Pengaruh Kualitas Pelayanan Terhadap Tingkat Kepuasan Nasabah Pada Bank Muamalat Cabang Solo, . Surakarta: STAIN.

Umar, H. (2003). Riset Sumber Daya manusia dalam Organisasi. Jakarta: PT Gramedia Pustaka Utama., 


\section{JESYA}

JURNAL EKONOMI \& EKONOMI SYARIAH

Jurnal Ekonomi \& Ekonomi Syariah Vol 5 No 1, Januari 2022

E-ISSN : 2599-3410 | P-ISSN : 2614-3259

DOI : https://doi.org/10.36778/jesya.v5i1.530

Wijoyo, Nugroho Agung (2021) Kajian Persaingan Bank Umum di Indonesia, Pusat Kebijakan Sektor Keuangan, https://fiskal.kemenkeu.go.id/kajian/2021/01/08/101700047756377kajian-persaingan-bank-umum-di-indonesia

Yazit. ( 2005). Pemasaran Jasa, Konsep dan Implementasi. Yogyakarta: EKONISIA. 